\title{
Is There a Link Between Industry Involvement in Higher Education Learning and Student Job Creation Intention?
}

\begin{tabular}{|c|l|}
\hline Journal: & Industry and Higher Education \\
\hline Manuscript ID & IHE-20-0158.R2 \\
\hline Keywords: & $\begin{array}{l}\text { Industry involvement, higher education learning, job creation intention, } \\
\text { curriculum restructuring }\end{array}$ \\
\hline & $\begin{array}{l}\text { This study examines how the constituents of industry involvement in } \\
\text { higher education learning (IIHEL), namely; curriculum restructuring, } \\
\text { renewed pedagogical approaches and competencies, building linkages } \\
\text { between higher education and industry, and career training and } \\
\text { mentoring might impact student job creation intention. The study builds } \\
\text { on the social cognitive theory (self-efficacy) and the theory of planned } \\
\text { behaviour (attitude towards behaviour) to assess the mechanisms } \\
\text { through which these relationships exist. The researchers used cross- } \\
\text { sectional data from 268 final-year undergraduate students of 12 Nigerian } \\
\text { public universities to analyze these relationships. Structural equation } \\
\text { modelling analysis (SEM-AMOS) was employed to test the direct } \\
\text { relationships, and Hayes PROCESS Macro 3.5 was used to test the } \\
\text { specific indirect effects. Findings show that all the constituents of IIHEL } \\
\text { were associated positively with student job creation intention. However, } \\
\text { only self-efficacy mediated the relationships between curriculum } \\
\text { restructuring, renewed pedagogical approaches and competencies and } \\
\text { student job creation intention. The findings provide practical implications } \\
\text { for higher education teachers, managers, practitioners, policymakers and } \\
\text { students by demonstrating the importance of IIHEL in boosting student } \\
\text { job creation intention. }\end{array}$ \\
\hline Abstractions \\
\hline
\end{tabular}

\section{SCHOLARONE" Manuscripts}




\title{
Article type: Article
}

\section{Is there a link between industry involvement in higher education learning and student job creation intention?}

\author{
Authors: \\ Christian Ehiobuche \\ Stockton University, USA. \\ Ugochukwu Chinonso Okolie \\ Alex Ekwueme Federal University, Nigeria \\ Anthony Chukwuma Nwali \\ Alex Ekwueme Federal University, Nigeria \\ Paul Agu Igwe \\ University of Lincoln, UK

\section{Corresponding author:}

Ugochukwu Chinonso Okolie, Department of Vocational and Technology Education, Alex Ekwueme Federal University, 6 Chief Jioke Ugo Street, Abakaliki, Ebonyi State 480213, Nigeria. Email: nonyeck@gmail.com

\begin{abstract}
:
This study examines how the constituents of industry involvement in higher education learning (IIHEL) - namely curriculum restructuring, renewed pedagogical approaches and competencies, building linkages between higher education and industry, and career training and mentoring - might impact student job creation intention. The study builds on social cognitive theory (self-efficacy) and the Theory of Planned Behaviour (attitude towards behaviour) to assess the mechanisms through which these relationships exist. The researchers used cross-sectional data from 268 final-year undergraduate students of 12 Nigerian public universities to analyze these relationships. Structural equation modelling analysis (SEMAMOS) was employed to test the direct relationships, and Hayes' PROCESS Macro 3.5 was used to test the specific indirect effects. The findings show that all the constituents of IIHEL were associated positively with student job creation intention. However, only self-efficacy mediated the relationships between curriculum restructuring, renewed pedagogical approaches and competencies and student job creation intention. The findings provide practical implications for higher education teachers, managers, practitioners, policymakers and students by demonstrating the importance of IIHEL in boosting student job creation intention.
\end{abstract}


Keywords: Industry involvement in learning, higher education learning, job creation intention, curriculum restructuring, Theory of Planned Behaviour, social cognitive theory

We live in a highly competitive global society, which requires a rapid evolution of the labour market to deliver the needs of society in terms of products and services (Alonso et al., 2010). To ensure that such demands are met, there must be a supply of competent and skilled graduates to act as either employers or employees. Thus there is a requirement for higher education institutions (HEIs) to produce graduates who have developed work-related or business start-up knowledge, skills and attitudes so that they can work effectively in established firms or start their own business and create jobs for others. This is especially important in light of the increasing number of student enrolments, lack of graduate jobs and rising underemployment (Karmel and Carroll, 2016; Valentin, 2000). In Nigeria, for instance, 40 per cent of the total population, or almost 83 million people, live below the country's poverty line of 137,430 Naira (\$381.75) per year and do not have a job to earn a livelihood (World Bank (2019). This situation has led to the Nigerian government's policy on promoting entrepreneurship or small business start-up as a means of reducing poverty, creating more jobs and helping people to improve their living standard (e.g., Otache, 2019). Furthermore, the drive for HEIs to engage or partner with industry in the effort to produce competent graduates who can start their own businesses and create jobs has attracted many researchers in recent years. Also, various initiatives have emerged in the search for sustainable strategies to improving higher education-industry linkages and so develop more industry-aware graduates (Allen and Williams, 2005; Hurn, 2016; Plewa et al., 2015).

Skilbeck and Connell $(2004$, p. 7) have explained that 'successful learning at school is the foundation of lifelong learning by individuals in the globalized, knowledge society of the future'. This means that, through effective teaching and learning, graduates can acquire relevant knowledge and skills that may increase their job creation intention. Also, students who participate in other career development programmes, such as extra-curricular activities, exposure to problem-based learning and work placements, may develop the knowledge and skills to start a business after graduation that will boost their job creation intentions (Dickinson 
and Griffiths, 2017). Given the lack of jobs available and the overwhelming numbers of student enrolment in HEIs (Okolie et al., 2019), a key priority in ensuring positive graduate outcomes is to boost student job creation intention and the overall quality of students' work, career and business start-up knowledge and skills (Franco et al., 2019).

Students' intentions to start their own businesses and so to create jobs can be a good indicator of the quality of graduate outcomes. Academic and policy reports have outlined useful ways in which HEIs and industry can partner to improve those outcomes (Okunuga and Ajeyalemi, 2018; Pitan, 2016), yet an important issue remains conspicuously absent: industry involvement in higher education learning (IIHEL) and its implications for student job creation intention. Evidence suggests that graduates are more likely to develop skills and knowledge for work or business start-up when industry experts are involved in the design and delivery of learning in higher education (Okolie et al., 2020b).

IIHEL refers to the extent to which students perceive that employers are part of the learning they receive and ensure that they are prepared for the world of work (Okolie et al., 2020a). It has been associated with shared benefits for students (e.g., employability skills development, commitment to learning and engagement, etc.), higher education (e.g., producing competent graduates, training teachers in the use of student-centred approaches, accepting students into internship programmes, encouraging and promoting skill-driven learning instead of certificate-driven learning, etc.) and industry (e.g., productivity, recruitment of competent graduates trained in line with the demands of labour market, job creation, networking, etc.) (Callanan and Benzing, 2004). Despite these benefits, the links between IIHEL and student job creation intention have received scant attention in the research literature. Therefore, there is a paucity of empirical insights into how IIHEL might influence student job creation intention and the mechanisms mediating such relationships. This is an important empirical and theoretical gap that the present study intends to explore systematically. 
This study draws on that of Okolie et al. (2020a) which identifies factors that contribute to students' knowledge and skill development, and includes recommendations for (i) curriculum restructuring, (ii) renewed pedagogical approaches and competencies (REPAC), (iii) building effective linkages between higher education and industry (BELHI), and (iv) career training and mentoring (CTM) as effective practices for IIHEL. The goal of the present study is to determine how each of these four constituents of the recommended framework for IIHEL might boost student job creation intention and the mechanisms through which IIHEL might influence student job creation intention. Using cross-sectional data from final-year undergraduate students who had undertaken a compulsory industrial work placement, the study applies a robust empirical analysis to a set of complementary hypotheses (Figure 1).

\section{Insert Figure 1 about here}

The study contributes to the literature in several ways. It provides deeper insights into how IIHEL might engender positive job creation intention among undergraduate students, and so ultimately improve business start-up intention and behaviours - the former being a fairly neglected domain in industry and higher education research. The authors acknowledge previous research showing that IIHEL can provide various benefits (e.g., Okolie et al., 2020a; Dickinson and Griffiths, 2017); yet, the direct implications for student job creation intention are not fully understood. Our study addresses an important research gap, highlighting useful ways to develop students' job creation intention and improve higher education-industry partnerships to improve the quality of graduate outcomes. The study draws on social cognitive theory (SCT) and the Theory of Planned Behaviour (TPB) to address this research gap. Considering the importance attributed to graduate venture creation and its impact on job creation, it is appropriate to explore how IIHEL can facilitate student job creation intention (e.g., Krueger and Carsrud, 1993; Matricano, 2019; Nabi et al., 2006). 


\section{Literature Review and Theoretical Background}

The existing literature on the constructs of IIHEL, the theories, and job creation intention are reviewed in this section to provide information on previous studies and to develop the hypotheses.

\section{Job Creation Intention}

Job creation intention has been defined in many ways: as the intention to start a business venture, to own a business, to become self-employed or to employ others (Zhao et al., 2005). Producing graduates who are more entrepreneurial and so able to contribute to solving social problems has become a priority of the Nigerian government, and HEIs have been making efforts to encourage students to start their own businesses after graduation and so to create jobs (e.g., Otache, 2019). Student job creation intention may be improved by IIHEL - a partnership that can motivate students to be entrepreneurial. This study acknowledges that students' intentions to become entrepreneurial and/or to create jobs after graduation may be motivated by many factors, including, for example, parents' ownership of a business or other family and peer influences. However, IIHEL is a major factor that can motivate student job creation intention since it enhances knowledge and skills for job creation (Okolie et al., 2020a).

The intention to become self-employed or create jobs after graduation can be seen as a predictor of entrepreneurial engagement (Kautonen et al., 2015). We acknowledge that entrepreneurship education and other entrepreneurial activities take place in the HEIs of many countries and that, in many cases, participation in entrepreneurship courses is a mandatory requirement for graduation. However, previous studies have questioned the ability of entrepreneurship courses and initiatives promoted by higher education to enhance students' entrepreneurial aspirations and intentions (Otache, 2019). For example, Støren (2014) found that, among Norwegian graduates, those who had studied entrepreneurship-related courses as 
part of their curriculum had no greater intentions to start their own business than other graduates. Barba-Sánchez and Atienza-Sahuquillo (2018) also found no influence of entrepreneurship education on business start-up intention among Spanish engineering students. These reports are indications that entrepreneurship education may not be enough in itself to motivate student job creation intention. Hence the need for IIHEL and higher education curriculum restructuring.

\section{Curriculum Restructuring}

The emphasis on student job creation intention "raises awareness that graduates' ability to create jobs requires the restructuring of HE curriculum to include programmes and activities that support the development of entrepreneurial knowledge and skills" (Okolie et al., 2020a, p. 5). Restructuring the curriculum to include such programmes and activities can help to reduce many theory-based courses offered in the HE, which may limit students' intentions to start their own businesses leading to job creation after graduation. Seasoned industry experts and HE policymakers whose entrepreneurial ideas and skills are well known can be integrated into the design and delivery of the course modules or activities. These experts can help by identifying the needs of society for technological innovation, manpower development and economic growth. This can encourage more undergraduates to consider the option of a career within the small business sector or through starting their own businesses (e.g., Holden et al., 2002; Nabi et al., 2006).

Also, Okolie et al. (2020a, p. 5) identified a demand for "a more vocational/professional curriculum, which would emphasize the development of specific skills in addition to disciplinespecific knowledge" and that would "support multidisciplinary knowledge and encourage student-centred and problem-based learning which foster skills for starting businesses" after graduation. Curriculum restructuring can enable HEIs to offer students greater choice and 
control over their learning and hence increase their entrepreneurial or job creation intentions. Karseth (2006) has explained that curriculum restructuring implies an outward orientation, where the student as a potential consumer is placed at the centre. Curriculum restructuring can, furthermore, facilitate renewed pedagogical approaches and competencies (REPAC) and be a means of advocating student-based learning and a learner-centred curriculum which might help students to develop knowledge and skills that will spur their job creation intention (Moore, 2003; Scott and Watson, 1994). Thus we might expect a positive relationship between curriculum restructuring and student job creation intention.

Hypothesis 1: Curriculum restructuring on the recommendations of industry experts is directly and positively associated with student job creation intention.

REPAC

In promoting industry support for entrepreneurship education, setting up innovation hubs, promoting industry-HE partnerships and encouraging student business start-ups, REPAC is very relevant. For example, Okolie et al. (2020a, p. 6) found that "poor teaching approaches used by a majority of teachers in Nigeria might be hindering students' successful development of entrepreneurial capabilities". The inability of teachers to use effective pedagogical approaches that can engage students and motivate them to construct meaningful learning may hinder their development of knowledge and skills for job creation after graduation. REPAC concerns innovative pedagogical approaches that allow interactive, experimental, transformative and real-world learning (e.g., Brundiers et al., 2010; Seatter and Ceulemans, 2017). Such approaches can facilitate the generic skills development that students need for successful business start-up after graduation. However, it is important to acknowledge that the choice of pedagogical approach depends largely on the educational goals and the specifics of the situation, such as the learning environment (De Freitas and Oliver, 2005). 
Furthermore, REPAC requires that teachers in higher education undertake continuing professional development (CPD) to keep their pedagogical competencies up to date. This CPD can enable them to understand students' diverse learning needs and to identify the best approach for stimulating job creation intention. Okolie et al. (2020a, p. 7) argue that introducing and adopting teaching approaches such as "problem-based learning, practice-based learning, work-based learning, collaborative learning, self-directed learning, and competencybased learning in addition to the traditional teaching methods can help students to develop theoretical knowledge and practical skills". The present study, therefore, argues that, through REPAC, building effective linkages between higher education and industry (BELHI) becomes possible and that students can develop critical thinking skills, become able to recognize opportunities, and build interest in starting and running a business after graduation (e.g., UNESCO, 2012). Given these potential benefits of REPAC, this study predicts a positive relationship between REPAC and student job creation intention.

Hypothesis 2: REPAC is directly and positively associated with student job creation intention.

\section{BELHI}

Previous studies have reported that effective linkages between industry and higher education facilitate industry's input into learning (Callanan and Benzing, 2004). It has also been recognized that an increase in such linkages can promote students' development of economybased knowledge, competitiveness and the motivation to create new businesses for job creation (e.g., Cassiman and Veugelers, 2007; Thune, 2011). Okolie et al. (2020a, p. 7) found that these linkages could strengthen existing entrepreneurship education through career development learning, work placement programmes, career mentoring, career fairs, innovation hubs and business start-up ideas. 
While many studies have reported the difficulty of creating a specific typology to classify higher education-industry linkages (e.g., Chau et al., 2017; Monjon and Waelbroeck, 2003), others have found positive higher education-industry linkages (Al-Tabbaa and Ankrah, 2016; Faems et al., 2005). Kaklauskas et al. (2018), for example, found that effective linkages improved technological development and increased productivity. Such findings highlight the importance of BELHI in the integration of classroom learning with real-world practical experiments and career training and mentoring (CTM), strengthening students' ability to operate effectively as professionals or entrepreneurs after graduation. By extension, we argue that BELHI will have positive effects on other graduate outcomes, such as students' sense of empowerment, information and opportunity seeking, creativity and problem-solving, selfconfidence, goal setting, networking and professional contacts, which can boost their job creation intention.

Hypothesis 3: BELHI is directly and positively associated with student job creation intention.

\section{CTM}

Through IIHEL, CTM can be provided to students in the form of activities and programmes that will help them develop an interest in pursuing career goals or in starting a business. Okolie et al. (2020b, p. 217) define CTM as organized training or activities and practices that involve professionally trained counsellors to provide the high-quality careers advice, coaching and mentoring that are vital for students to make informed career decisions. They further explain that CTM differs from other career education programs in that, while other programmes are publicly offered to many students, CTM applies to both public and one-on-one support. In line with this definition, we refer to CTM as carefully planned career training with one-on-one coaching support that should be provided free to students to enhance their lifelong learning and 
business creation intentions. This important academic activity can help reduce graduate-job mismatch in that students will have an opportunity to interact face-to-face with industry and business development experts.

To promote effective CTM, Okolie et al. (2020b) recommended that HEIs should establish dedicated CTM centres, managed by professionally trained career experts or teachers in the field of career development. With such support, students will have easy access to business and job-related information, and will be able to obtain informative responses to business start-up questions that will stimulate their job creation intentions. We argue that CTM activities and programmes such as job fairs, placement training, career and business talks, seminars, business start-up workshops, supervised internships and entrepreneurship education may boost interest in business creation. Furthermore, while explaining the procedures for establishing a CTM centre in an HEI is beyond the scope of this paper, we argue that CTMs can enhance the provision of up-to-date business start-up information, ease the school-to-work transition, facilitate choice-making, and improve training and mentoring on graduate venture creation.

Hypothesis 4: CTM is directly and positively associated with student job creation intention.

This study draws on two major theories relating to psychology and management - the Theory of Planned Behaviour (TPB) and social cognitive theory (SCT) - to explain the relationship between IIHEL and job creation intention. In this study, key elements (one from each) of these theories form the mediating variables through which IIHEL may influence students' job creation intention. First, the TPB has been effectively used to explain a range of topics in intention and behavioural research (e.g., Lindstrom-Forneri et al., 2007; Van der Linden, 2011). Student job creation intention is a planned response rather than a spontaneous 
decision (Krueger et al., 2000; Lingappa et al., 2020). As Ajzen (1991) explained in the TPB model, attitude toward behaviour, subjective norms and perceived behavioural control are the three factors that explain an individual's intention to engage in certain behaviour. However, our focus here is only on the attitude toward behaviour (students' attitude toward job creation). Since job creation intention is believed to be an entrepreneurial behaviour, the TPB is useful in explaining the processes leading to student job creation behaviour through the 'attitude toward behaviour' constituent of the model. However, in this paper we refer to the attitude toward behaviour as the 'mindset' of the student toward job creation behaviour.

Second, SCT (Bandura, 1977) refers to self-efficacy belief as "a mechanism of operation" that involves an individual's conviction that they will successfully implement actions leading to a desired outcome. Self-efficacy has been identified as a successful mediator in career or business development outcomes - specifically, interest development, decisionmaking and performance attainment (Lent and Brown, 2013). According to Luszczynska et al. (2005, p. 439), self-efficacy is "the belief in one's competence to cope with a broad range of stressful or challenging demands". It has the ability to influence intention, self-regulation and outcome expectations (Luszczynska et al., 2005). As Zhao et al., (2005, p. 1267) explain, "selfefficacy represents a central mechanism of personal agency. It is thought to influence not only one's level of effort and persistence on a specific task but one's very choice of activities and behavioural settings". Studies have reported that self-efficacy is positively related to business venture creation intention (e.g., Zhao et al., 2005; Wang et al., 2016). Thus the present study considers self-efficacy in the relationship between IIHEL and student job creation intention. We argue that self-efficacy and attitude toward behaviour mediate that relationship:

Hypothesis 5: Attitude toward behaviour mediates the relationship between IIHEL constituents and student job creation intention. 
Hypothesis 6: Self-efficacy mediates the relationship between IIHEL constituents and student job creation intention.

\section{Method}

\section{Sample and Procedure}

This is a cross-sectional study for which data were collected from final-year undergraduate students of Nigerian public universities during April to August 2020. The undergraduates had undertaken a three- to six-month compulsory industrial work placement and completed all mandatory entrepreneurship education courses. They could therefore offer relevant information concerning the practical application of SCT and the TPB through education and training for national productivity and job creation. We adopted an online data collection procedure, designing the questionnaire using Google Forms. The questionnaire was accompanied by a consent note explaining that participation was voluntary, and that the data and responses would be confidential and used for research purposes only (Onwuegbuzie and Collins, 2007). As a follow-up study to the previously published qualitative study (Okolie et al., 2020a), the email and WhatsApp contacts of the 17 final-year undergraduate students who participated in that study were used.

The link to the online questionnaire was shared with participants' contacts and they were encouraged to respond to the questionnaire and share the link with colleagues in other Nigerian public universities who were in their final-year undergraduate programme and had completed the compulsory industrial work placement programme. Through this approach, 289 responses were received in the four months of data collection. After removing 21 incomplete responses, the remaining 268 responses were used for the final dataset. These 268 respondents were final-year undergraduate students from the following faculties in 12 Nigerian public universities: Education (56 respondents, 20.89\%), Agriculture (43, 16.04\%), Engineering (51, 19.03\%), Natural and Applied Sciences (33, 12.31\%), Management Sciences (44, 16.43\%) and 
Biological Sciences (41, 15.30\%). Respondents were aged between 21 and 28, and 172 (64.18\%) were male and 96 female.

\section{Measures}

Student job creation intention. Intention was measured through responses to six adapted statements relating to students' intentions to become entrepreneurs (Liñan and Chen, 2009) for example, "I am determined to create my own business after graduation to create jobs". Responses ranged from 1 (strongly disagree) to 5 (strongly agree). The scale has a Cronbach's $\alpha$ of 0.9 ; however, our $\alpha$ was 0.85 .

Attitude towards behaviour. This was measured through an adapted 5-item scale relating to the students' attitude towards business start-up leading to job creation (Liñan and Chen, 2009) for example, "A career as an entrepreneur is attractive to me". Responses ranged from 1 (strongly disagree) to 5 (strongly agree). The scale reported a Cronbach's $\alpha$ of 0.89 , and ours was also 0.89 .

Self-efficacy. We adapted the 9-item entrepreneurial self-efficacy sub-scale (Wang et al., 2019) - for example, "I possess the ability to be an entrepreneur". Responses ranged from 1 (strongly disagree) to 5 (strongly agree). The scale developer reported a Cronbach's $\alpha$ of 0.84 , while our $\alpha$ was 0.96 .

Curriculum restructuring. We adapted the fundamental change scale of school restructuring and student achievement in Washington state of Fouts et al. (1999), altering the wording of some items to suit the context of the study - for example, "I will be better prepared as a result of the changes the curriculum restructuring will bring". Responses ranged from 1 (strongly 
disagree) to 7 (strongly agree). The original scale reported an $\alpha$ value of 0.87 while our $\alpha$ was 0.95 .

$R E P A C$. Given the lack of a validated scale, we self-developed a 10 -item scale to measure students' perceptions of renewed pedagogical approaches and the competencies of teachers, first conducting a pilot study following recommended scale development procedure (Carpenter, 2018). Statements included, for example: "I will be better prepared as a result of renewed pedagogical approaches and competencies of my teachers". Responses ranged from 1 (strongly disagree) to 7 (strongly agree). The Cronbach's $\alpha$ was 0.81 .

BELHI. We self-developed a 7-item scale to measure students' perceptions of building effective Higher education-industry linkages. As for the REPAC scale, we conducted a pilot study following recommended scale development procedure (Carpenter, 2018). Statements included, for example: "My entrepreneurial intentions will improve as a result of effective linkages between my university and industry”. Responses ranged from 1 (strongly disagree) to 7 (strongly agree). The Cronbach's $\alpha$ was 0.77 .

CTM. We adapted the 6-item career dimension and mentoring effectiveness subscale of Dilmore et al. (2010). Statements included, for example: "I will learn more strategies for achieving career aspirations". The responses ranged from 1 (strongly disagree) to 7 (strongly agree). The original scale reported a Cronbach's $\alpha$ value of 0.95 ; our $\alpha$ was 0.88 .

Control variables. We controlled for age and gender of the undergraduates to ascertain whether they might influence job creation intentions. Also, Curran et al. (1991) found that people whose parents were owners of small firms might want to follow in their parents' footsteps and become business owners. Therefore, we controlled for parental self-employment. 


\section{Analytical procedure}

We conducted a confirmatory factor analysis (CFA) using Amos 24.0 to test the measurement model fit indices. The latent variables representing curriculum restructuring, REPAC, BELHI, CTM, self-efficacy, attitude towards behaviour and student job creation intention made up the measurement model. The overall goodness-of-fit was considered adequate: $\chi^{2}=423.01$; $\mathrm{df}=$ $149 ; \chi^{2} / \mathrm{df}=2.84 ; \mathrm{CFI}=0.94, \mathrm{TLI}=0.92, \mathrm{SRMR}=0.05, \mathrm{IFI}=0.93$, and $\mathrm{RMSEA}=0.06$, indicating an acceptable model fit (Hu and Bentler, 1999). Focusing on the contents of the items for measuring the variables, we gradually removed items that loaded below 0.50 during principal axis factorial analysis in SPSS, as well as items that had standardized regression weights smaller than 0.70 during the CFA in AMOS (Hair et al., 2010).

\section{Model validity and reliability measures}

The indicator factor loadings are significant and exceed the acceptable value of $\geq 0.6$ on their corresponding constructs. Convergent validity was established, as the average variance extracted (AVE) is $\geq 0.50$. Discriminant validity was established, as the square root of AVE is greater than the correlation of the latent variables in the CFA (Fornell and Larcker, 1981). Also, in line with Hair et al. (2010), Cronbach's alpha and composite reliability values are $\geq 0.70$ and $\geq 0.60$, respectively, while the factor loadings are $\geq 0.50$ (see Table 1 ).

\section{Table 1 about here}

\section{Results}

As shown in Table 2, the bivariate analysis indicated that all the constituents of IIHEL curriculum restructuring $(r=0.17, p<0.01)$, REPAC $(r=0.40, p<0.01)$, BELHI $(r=0.17, p$ $<0.01)$ and CTM $(r=0.18, p<0.01)$ - were positively correlated with student job creation 
intention. Also, attitude towards behaviour $(r=0.13, p<0.05)$ and self-efficacy $(r=0.16, p$ $<0.05)$ were positively correlated with student job creation intention.

\section{Table 2 about here}

To ascertain whether curriculum restructuring, REPAC, BELHI and CTM would significantly predict student job creation intention, self-efficacy and attitude towards behaviour, we tested direct relationships using structural equation modelling (AMOS 24.0) and by applying bias-corrected 2,000 resample bootstraps to determine all direct effects (at a 95\% confidence interval) simultaneously. Table 3 shows the parameter estimates for all direct effects in the model. The model fit measures for the SEM analysis (final model) indicated an acceptable fit $\left(\mathrm{Hu}\right.$ and Bentler, 1999): $\chi^{2}=36.99 ; \mathrm{df}=17.00 ; \chi^{2} / \mathrm{df}=2.18 ; \mathrm{CFI}=0.93, \mathrm{GFI}=$ $0.97, \mathrm{IFI}=0.94 ; \mathrm{SRMR}=0.05, \mathrm{RMSEA}=0.06$, PClose $=0.16$

In this model (Table 3), all five constituents of IIHEL were associated positively with student job creation intention: curriculum restructuring $(\beta=0.13, p<0.001)$, REPAC $(\beta=$ $0.27, p<0.001)$, BELHI $(\beta=0.17, p<0.001)$, and CTM $(\beta=0.13, p<0.001)$. This provides full support for hypotheses $1,2,3$ and 4 . Also, curriculum restructuring $(\beta=-0.02, p=0.75)$, BELHI $(\beta=-0.01, p=0.92)$ and CTM $(\beta=0.11, p=0.10)$ were not significantly associated with attitude towards behaviour. Only REPAC $(\beta=0.34, p<0.001)$ was associated positively with attitude towards behaviour. The analysis shows that only curriculum restructuring $(\beta=0.12, p<$ $0.05)$ and REPAC $(\beta=0.16, p<0.001)$ were significantly and positively associated with selfefficacy. However, BELHI $(\beta=-0.08, p=0.22)$ and CTM $(\beta=0.07, p=0.30)$ were not significantly associated with self-efficacy.

The effects of the mediators on student job creation intention were all significantly positive: attitude towards behaviour $(\beta=0.15, p<0.001)$ and self-efficacy $(\beta=0.34, p<$ 0.001 ). Also, $5.30 \%$ of the variance in self-efficacy, $13.50 \%$ in attitude towards behaviour and $45.60 \%$ in student job creation intention was accounted for in this study (Table 3). 
For covariates, the results show that age $(\beta=-0.17, p<0.05)$ was associated negatively with student job creation intention. A possible interpretation of this result is that the lower the age of the student, the lower their job creation intentions. Also, parents' ownership of business $(\beta=0.26, p<0.001)$ was associated positively with student job creation intention, indicating that students whose parents own a business may be more likely to have intentions to start a business after graduation. This finding corroborates previous findings that students whose families have business enterprises are generally inclined towards entrepreneurial intentions (e.g., Curran et al.,1991; Harris and Gibson, 2008). However, there is no statistically significant evidence that gender $(\beta=0.03, p<0.21)$ is associated with student job creation intention (see Table 3).

For mediation, the predictors should be related to the mediators and the outcome; the mediators should be related to the outcome, and the relationships between the predictors and outcome should be reduced when the mediators are included (Baron and Kenny, 1986). The regression analysis showed that curriculum restructuring and REPAC were associated positively with the mediators self-efficacy and attitude towards behaviour (Table 3). Therefore, following Shrout and Bolger (2002), mediation can take place only through these paths. To test for specific indirect effects, we followed the procedure outlined by Hayes $(2018$, p. 144) - the "kX variables PROCESS commands" - to find the specific indirect effects.

Table 3 about here

We, used Hayes PROCESS Macro 3.5, applied Model 4 and 5,000 resample bootstrap method to determine the indirect effects. Table 3 (indirect effects) shows that self-efficacy $(\beta$ $=0.05, C I s=[0.01,0.10], p<0.001)$ mediated the relationship between curriculum restructuring and student job creation intention. Similarly, the analysis shows that self-efficacy $(\beta=0.04, C I s=[0.01,0.09], p<0.001)$ mediated the relationship between REPAC and student 
job creation intention. However, there is no evidence of mediation in the relationship between BELHI, CTM and student job creation intention via self-efficacy or attitude towards behaviour.

\section{Discussion}

Relying on SCT and the TPB, we assessed a model of undergraduate student job creation intention. Ascertaining how the constituents of IIHEL - curriculum restructuring, REPAC, BELHI and CTM (Okolie et al., 2020a) - can foster final-year undergraduate student job creation intention contributes significantly to our understanding of the intention to start new businesses leading to job creation in this population. As far as we know, no previous studies have drawn on SCT and the TPB to test the relationships among curriculum restructuring, REPAC, BELHI, CTM, self-efficacy, attitude towards behaviour and student job creation intention in a single comprehensive model. Our model proposed that the constituents of IIHEL were related to students' job creation intention, and we found full support for the hypothesized model. Also, our model proposed that self-efficacy and attitude towards behaviour mediated these relationships, and we found that self-efficacy mediated the relationships between curriculum restructuring and student job creation intention. We also found that self-efficacy mediated the relationship between REPAC and student job creation intention. We now discuss the most important contributions of the study.

First, curriculum restructuring was associated positively with student job creation intention. A possible interpretation of this finding is that, through effective curriculum restructuring via a joint effort by teachers, industry executives and policymakers to include business start-up activities or programmes, students may be more likely to develop the intention to create a business after graduation, leading to job creation. This result corroborates previous findings that linked curriculum restructuring to student business start-up or job creation intentions (e.g., Krueger et al., 2000; Nabi et al., 2006; Tessema, 2012). According to Okolie 
et al. (2020a, p. 7), "the curriculum is the main focal point in developing entrepreneurial and job creation skills and universities cannot achieve that outcome by themselves, so the engagement of industry in refocusing the curriculum and programme design is imperative".

Also, the study revealed that curriculum restructuring was positively associated with self-efficacy and attitude towards business. This indicates that restructuring the curriculum to include more practical entrepreneurial activities will play a significant role in activating students' job creation self-efficacy and attitudes toward future job creation. This result supports the view that restructuring the curriculum to include business start-up and development activities can boost students' perception of their self-efficacy and their confidence to execute behaviours necessary to start a business (this is consistent with previous findings - see Nabi, 2006; Peterman, 2003).

Second, REPAC was positively associated with student job creation intention. This indicates that renewing the pedagogical approaches used by the teachers as well as their competencies will play a significant role in boosting students' interest in starting a business after graduation. A possible interpretation of this finding is that, through REPAC, teachers can be empowered to use various innovative teaching approaches to activate a set of business startup behaviours in students to improve their intentions to become future employers of labour. This result supports the view that innovative pedagogical approaches, such as, among others, work-based learning, problem-based learning and student-centred learning, can improve the successful development of entrepreneurial capabilities and increase job creation intention. This corroborates the previous finding that REPAC can encourage higher education teachers to "be proactive in planning and delivering their teaching. For example, in addressing real-life challenges in companies, students can find solutions through problem-based learning, thus developing business acumen" (Okolie et al., 2020a, p. 7). Also, REPAC was associated positively with self-efficacy and attitude towards behaviour. By implication, improving 
teachers' competencies and using an appropriate teaching approach can improve students' selfefficacy or belief in their ability to start-up businesses after graduation. This can also improve students' attitude towards behaviours relating to becoming a future entrepreneur.

Third, the results showed that BELHI was positively associated with students' job creation intention. This indicates that effective higher education-industry linkages are likely to improve the integration of classroom learning with real-world practical experiments, which can strengthen students' ability to operate effectively as entrepreneurs after graduation. Callanan and Benzing (2004) suggest that, through effective linkages, new and existing industries in and outside an HEI's host community can be involved in improving student learning by voluntary training of students in job creation skills. Franco et al. (2019) find that professional learning programmes or activities provided by industry-higher education linkages play a crucial role in students' entry into a labour market characterized by strong competition. As Lam and Ching (2007) argue, effective linkages can help students to bridge the gap between the academic learning process and practical realities. Surprisingly, we found no evidence that BELHI was positively associated with self-efficacy and attitude towards behaviour in this population.

Fourth, our study revealed that CTM was positively associated with student job creation intention. This result indicates that students who received adequate career training and mentoring in business start-up may be more likely to have job creation intentions. The result also supports the view that adequate career-related advice and mentoring can increase students' business start-up orientation, which can boost job creation intention (Otache, 2019). A possible interpretation of this finding is that students can be encouraged and mentored to share their career development problems with industry experts employed by their HEI. Such career-related interaction can provide students with up-to-date business start-up information that may boost their intention to become future employers of labour. However, there was no evidence that CTM influenced student self-efficacy and attitude towards behaviour in this population. 
Lastly, regarding the specific mediating effects of self-efficacy and attitude towards behaviour, our results show that only self-efficacy was supported. This implies that the relationship between curriculum restructuring and student job creation intention was mediated through self-efficacy. Also, self-efficacy mediated the relationship between REPAC and student job creation intention. These outcomes suggest that restructuring the curriculum and REPAC may not wholly explain increased job creation intention; rather, we need to take into account entrepreneurial activities included in the restructured curriculum, innovative teaching approaches and self-efficacy belief with regard to business start-up after graduation. However, this study found no evidence of mediating effects of self-efficacy and attitude towards behaviour in the relationships between BELHI, CTM and student job creation intention.

\section{Conclusion and implications}

This study shows that the constituents of IIHEL (curriculum restructuring, REPAC, BELHI and CTM) are significant positive predictors of student job creation intention. It reveals that the association between curriculum restructuring and REPAC and job creation intention may be due to the impact that curriculum restructuring has on the students' belief in their selfefficacy, which is associated with increased job creation intention. The findings thus advance our understanding of the role that IIHEL can play in student job creation intention and the study contributes to the literature on higher education-industry partnerships by not merely establishing a link between the previously recommended constituents of IIHEL (Okolie et al., 2020a) and student job creation intention, but by showing how self-efficacy mediates these relationships. The study has practical implications for teachers, students, practitioners and policymakers who are searching for innovative strategies to improve industry-higher education partnerships and students' job creation intention. Industry executives can help students to explore real-world practical experiments on business start-ups and provide them with the appropriate knowledge and skills to start and manage an enterprise after graduation. 


\section{Limitations and future research}

A major limitation of the study is the use of a cross-sectional design, which made causal inferences very difficult. However, this research does provide a better understanding of the mechanisms via which the constituents of IIHEL are associated with student job creation intention. Furthermore, the use of a self-reporting measure to evaluate variables may result in self-report bias or common method variance. We recommend that future research should use other measures, although we made efforts to reduce the risks of self-reporting bias by using different scales and response formats for the constituents of IIHEL and student job creation intention (Podsakoff et al., 2003). Another limitation relates to the small sample size, which limits the generalizability of the findings beyond the context of the current study. However, we applied the 5000 resample bootstrapping method which allows for generalization of the results to decrease this limitation (Hayes, 2018). We recommend that future studies use a larger sample and longitudinal data to provide further information about the IIHEL interventions needed to confirm the causal direction of these associations.

\section{References}

Ajzen, I. (1991). The theory of planned behaviour. Organizational Behavior and Human Decision Processes, 50, 179-211.

Al-Tabbaa, O., and Ankrah, S. (2016). Social capital to facilitate "engineered" universityindustry collaboration for technology transfer: a dynamic perspective. Technological Forecasting and Social Change, 104: 1-15

Allen, S., \& Williams, A. (2005). Measuring Engagement between Industry and Higher Education in the Built Environment Sector. Industry and Higher Education, 19(6), 457468. https://doi.org/10.5367/000000005775354509 
Alonso, J., de Soria, I.M., Orue-Echevarria, L. and Vergara, M. (2010). Enterprise collaboration maturity model (ecmm): Preliminary definition and future challenges. In Popplewell, K.,Harding, J., Poler, R. and Chalmeta, R. (Eds), Enterprise Interoperability IV, Springer London, London, pp. 429-438

Anne Støren, L. (2014). Entrepreneurship in higher education: Impacts on graduates' entrepreneurial intentions, activity and learning outcome. Education + Training, 56(8/9), 795-813.

Bandura, A. (1977). Social learning theory. Englewood Cliffs, NJ: Prentice Hall

Barba-Sánchez, V., and Atienza-Sahuquillo, C. (2018). Entrepreneurial intention among engineering students: The role of entrepreneurship education. European Research on Management and Business Economics, 24(1), 53-61.

Baron, R. M., and Kenny, D. A. (1986). The moderator-mediator variable distinction in social psychological research: Conceptual, strategic, and statistical considerations. Journal of Personality and Social Psychology, 51(6), 1173. https://doi.org/10.1037/00223514.51.6.1173

Brundiers, K., Wiek, A., and Redman, C.L. (2010). Real-world learning opportunities in sustainability: From classroom into the real world. International Journal of Sustainability in Higher Education, 11, 308-324.

Callanan, G. and Benzing, C. (2004). Assessing the role of internships in the career-oriented employment of graduating college students. Education \& Training, 46(2): 82-89.

Carpenter, S. (2018). Ten steps in scale development and reporting: A guide for researchers, communication methods and measures, 12(1), 25-44, https://doi.org/10.1080/19312458.2017.1396583 
Cassiman, B. and Veugelers, R. (2007). Are external technology sourcing strategies substitutes or complements: the case of embodied versus disembodied technology acquisition. IESE Business School - University of Navarra, Working Paper (672), 1-22.

Chau, V. S., Gilman, M., and Serbanica, C. (2017). Aligning university-industry interactions: the role of boundary spanning in intellectual capital transfer. Technological Forecasting and Social Change, 123, 199-209.

Curran, J., Blackburn, R. and Woods, A. (1991). Profiles of the small enterprise in the service sector, kingston university, ESRC Centre for Research on Small Service Sector Enterprise, Kingston.

De Freitas, S. and Oliver, M. (2005). Does e-learning policy drive change in higher education?: A case study relating models of organisational change to e-learning implementation. Journal of Higher Educational Policy Management, 27, 81-96

Dickinson, J., and Griffiths, T. (2017). Building bridges: A critical analysis of universityindustry collaboration to improve diverse access to elite professions. Industry and Higher Education, 31(4): 227-238.

Dilmore, T. C., Rubio, D. M., Cohen, E., Seltzer, D., Switzer, E. G., Bryce, C., Primack, B., Fine, M. J., and Kapoor, W. N. (2010). Psychometric properties of the mentor role instrument when used in an academic medicine setting. Clinical and Translational Science, 3(3), 104-108. https://doi.org/10.1111/j.1752-8062.2010.00196.x

Faems, D., Van Looy, B. and Debackere, K. (2005). Interorganizational collaboration and innovation: toward a portfolio approach. Journal of Product Innovation Management, $22(3), 238-250$.

Fornell, C. and Larcker, D. (1981). Evaluating structural equation models with unobservable variables and measurement error. Journal of Marketing Research, 18(1), 39-50 
Fouts, J. T., Baker, D., Newbill, G., Coyne, K., Stuen, C., Mork, C., and Van Slyke, R. (1999). School restructuring and student achievement in Washington State: Research findings on the effects of house bill 1209 and school restructuring on Western Washington Schools. https://files.eric.ed.gov/fulltext/ED432044.pdf

Franco, M., Silva, R., and Rodrigues, M. (2019). Partnerships between higher education institutions and firms: The role of students' curricular internships. Industry and Higher Education, https://doi.org/10.1177/0950422218819638.

Hair, J., Black, W. Babin, B. and Anderson, R. (2010). Multivariate data analysis (7th ed.). Upper Saddle River, NJ: Prentice-Hall.

Harris, M.L. and Gibson, S.G. (2008). Examining the entrepreneurial attitudes of US business students, Education + Training, 50(7), 568-81.

Hayes, A. F. (2018). Introduction to mediator, moderation, and conditional process analysis: A regression-based approach. ( $2^{\text {nd }}$ Ed). Guilford Publications.

Holden, R.J. and Jameson, S. (2002). Employing graduates in SME's: Towards a research agenda. Journal of Small Business an Enterprise Development, 9(3), 271-84.

Hu, L., and Bentler, P.M. (1999). Cutoff criteria for fit indexes in covariance structure analysis: Conventional Criteria Versus New Alternatives. Structural Equation Modelling, 6(1), $1-55$.

Hurn, K. M. (2016). Joined up thinking? Industry and Higher Education, 30(2), 129-139. https://doi.org/10.5367/ihe.2016.0298

Kaklauskas, A., Amaratunga, D., Haigh, R, Binkyte, A., Lepkova, N., Survila, A. Lill, I., Tantaee, S., and Banaitis, A. (2018) A model and system for an integrated analysis of the iterative life cycle of university-industry partnerships. Procedia Engineering, 212, $270-277$. 
Karmel, T., and Carroll, D. (2016). Had the graduate job market been swamped? Adelaide: National Institute of Labour Studies, Flinders University.

Karseth, B. (2006). Curriculum restructuring in higher education after the Bologna process: A new pedagogic regime? Revista Española de Educación Comparada, 12 (2006), 255284

Kautonen, T., van Gelderen, M., and Fink, M. (2015). Robustness of the theory of planned behavior in predicting entrepreneurial intentions and actions. Entrepreneurship Theory and Practice, 39(3), 655-674.

Krueger, N.F. Jr, Reilly, M.D.R. and Carsrud, A.L. (2000). Competing models of entrepreneurial intentions. Journal of Business Venturing, 15, 411-32

Krueger, N. F., and Carsrud, A. L. (1993). Entrepreneurial intentions: Applying the theory of planned behaviour. Entrepreneurship \& Regional Development, 5(4), 315-330. https://doi.org/10.1080/08985629300000020.

Lam, T. and Ching, L. (2007). An exploratory study of an internship program: The case of Hong Kong students. International Journal of Hospitality Management, 26(2), 336351.

LeBreton, J. and Senter, J. (2008). Answers to 20 questions about interrater reliability and interrater agreement. Organizational Research Methods, 11(4), 815-852.

Lent, R. W., and Brown, S. D. (2013). Social cognitive model of career self-management: Toward a unifying view of adaptive career behavior across the life span. Journal of Counseling Psychology, 60, 557-568.

Liñan, F. and Chen, Y.-W. (2009). Development and cross-cultural application of a specific instrument to measure entrepreneurial intentions. Entrepreneurship Theory and Practice, 33(3), 593-617. 
Lingappa, A. K., Shah, A., and Mathew, A. O. (2020). Academic, family, and peer influence on entrepreneurial intention of engineering students. SAGE Open, July-September, 1 12. https://doi.org/10.1177/2158244020933877.

Luszczynska, A., Scholz, U., and Schwarzer, R. (2005). The GSE scale: multicultural validation studies. J. Psychol. 139, 439-457. https://doi.org/10.3200/JRLP.139.5.439$\underline{457}$

Matricano, D. (2019). Higher education and start-up intentions: The role of intellectual capital in entrepreneurial processes. Industry and Higher Education, 34(3), 151-159. https://doi.org/10.1177/0950422219886259

Monjon, S. and Waelbroeck, P. (2003). Assessing spillovers from universities to firms: evidence from French firm-level data. International Journal of Industrial Organization, 21(9), 1255-1270

Moore, R. (2003). Curriculum restructuring in South African higher education: Academic identities and policy implementation. Studies in Higher Education, 28(3), 303-319. https://doi.org/10.1080/03075070309294

Nabi, G., Holden, R., and Walmsley, A. (2006). Graduate career-making and business start-up: a literature review. Education + Training, 48(5), 373-385. https://doi.org/10.1108/00400910610677072

Okolie, U. C., Nwajiuba, C. A., Eneje, B., Binuomote, M. O., Ehiobuche, C., and Hack-Polay, D. (2020a). A critical perspective on industry involvement in higher education learning: Enhancing graduates' knowledge and skills for job creation in Nigeria. Industry and Higher Education, 35(1): 61-72. DOI: 10.1177/0950422220919655.

Okolie, U.C., Nwajiuba, C.A., Binuomote, M.O., Ehiobuche, C., Igu, N.C.N. and Ajoke, O.S. (2020b). Career training with mentoring programs in higher education: Facilitating 
career development and employability of graduates. Education + Training, Vol. 62 No. 3, pp. 214-234. https://doi.org/10.1108/ET-04-2019-0071

Okolie, U. C., Nwosu, H. E, and Mlanga, S. (2019). Graduate employability: How the higher education institutions can meet the demand of the labour market. Higher Education, Skills and Work-Based Learning, 9(4), 620-636 https://doi.org/10.1108/HESWBL-09$\underline{2018-0089}$

Okunuga R. O. and Ajeyalemi D. (2018). Relationship between knowledge and skills in the Nigerian undergraduate chemistry curriculum and graduate employability in chemicalbased industries. Industry and Higher Education, 32(3), 183-191, https://doi.org/10.1177/0950422218766913

Onwuegbuzie, A.J. and Collins, K.M. T. (2007). A typology of mixed methods sampling designs in social science research. The Qualitative Report, 12(2), 281-316.

Otache, I. (2019). Entrepreneurship education and undergraduate students' self- and paidemployment intentions. Education + Training, 61(1), 46-64.

Podsakoff, P. M., MacKenzie, S. B., Lee, J.-Y., and Podsakoff, N. P. (2003). Common method biases in behavioral research: A critical review of the literature and recommended remedies. Journal of Applied Psychology, 88(5), 879. https://doi.org/10.1037/00219010.88.5.879.

Peterman, N. and Kennedy, J. (2003). Enterprise education: influencing students' perceptions of entrepreneurship. Entrepreneurship: Theory \& Practice, 28(2), 129-35.

Pitan, O. S. (2016). Employability development opportunities (EDOs) as measures of students' enhanced employability, Higher Education, Skills and Work-Based Learning, 6 (3): 288-304

Plewa C, Gala'n-Muros V and Davey T (2015) Engaging business in curriculum design and delivery: a higher education institution perspective. Higher Education, 70(1), 35-53. 
Scott, P., and Watson, D. (1994). Managing the curriculum. Roles and responsibilities, in J. BOCOCK, and D. WATSON (eds.), Managing the University Curriculum. Making a Common Cause, pp. 33-47 (Buckingham SRHE and Open University Press).

Seatter, C.S. and Ceulemans, K. (2017). Teaching sustainability in higher education: Pedagogical styles that make a difference. Canadian Journal of Higher Education, 47, $47-70$.

Shrout, P. E., and Bolger, N. (2002). Mediation in experimental and nonexperimental studies: New procedures and recommendations. Psychological Methods, 7, 422-445. https://doi.org/10. 1037/1082-989X.7.4.422

Skilbeck, M. and Connell, H. (2004). Teachers for the future. The changing nature of society and related issues for the teaching workforce. Report to the Teacher Quality and Educational Leadership Taskforce of the Ministerial Council on Education, Employment and Training. Canberra: Commonwealth of Australia Press.

Tessema, G. D. (2012). Impact of entrepreneurship education on entrepreneurial intentions of business and engineering students in Ethiopia. African Journal of Economic and Management Studies, 3(2), 258-277. https://doi.org/10.1108/20400701211265036

Thune, T. (2011). Success factors in higher education-industry collaboration: A case study of collaboration in the engineering field. Tertiary Education and Management, 17(1), 3150.

UNESCO. (2012). Education for Sustainable Development Sourcebook. Education for Sustainable Development in Action. Learning Training Tools N_4-2012; United Nations Educational, Scientific and Cultural Organization: Paris, France.

Valentin, E.M.M. (2000). University_industry cooperation: a framework of benefits and obstacles. Industry and Higher Education, 14(3), 165-172. 
Wang, Y.-S., Tseng, T.H., Wang, Y.-M. and Chu, C.-W. (2019). Development and validation of an internet entrepreneurial self-efficacy scale. Internet Research, 30 (2), 653-675. https://doi.org/10.1108/INTR-07-2018-0294

World Bank (2019). The 2019 Poverty and Inequality in Nigeria report. Retrieved from https://www.worldbank.org/en/programs/lsms/brief/nigeria-releases-new-report-onpoverty-and-inequality-in-country

Zhao, H., Seibert, S. E., and Hills, G. E. (2005). The mediating role of self-efficacy in the development of entrepreneurial intentions. Journal of Applied Psychology, 90(6), $1265-1272$. 


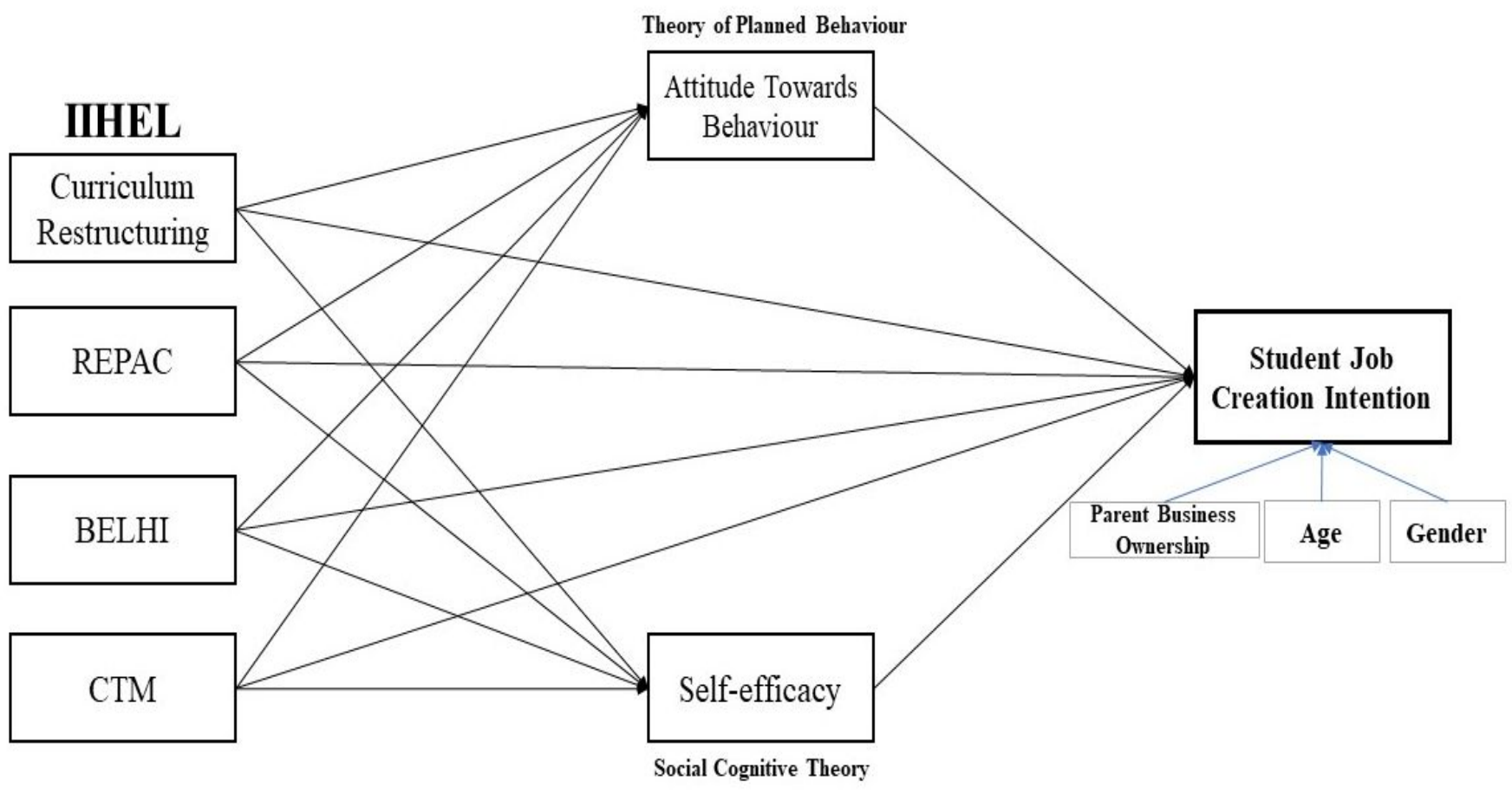

Figure 1. The hypotheses model.

Source: Authors' computation. 
Table 1. Measurement scale (model validity measures).

\begin{tabular}{|c|c|c|c|c|c|c|c|}
\hline Variables with observed items & $\begin{array}{c}\text { Indicators } \\
\text { (Items) }\end{array}$ & Loadings & $\mathbf{C R}$ & $\begin{array}{l}\text { Cronbach } \\
\text { Alpha }(\alpha)\end{array}$ & AVE & DV & MSV \\
\hline \multicolumn{8}{|l|}{ Curriculum restructuring } \\
\hline I will be better prepared as a result of the changes the curriculum restructuring would bring & CR5 & 0.92 & & & & & \\
\hline $\begin{array}{l}\text { My sense of learning will go beyond the classroom if the curriculum is restructured to } \\
\text { include business start-up activities }\end{array}$ & CR6 & 0.96 & & & & & \\
\hline $\begin{array}{l}\text { I will be caused to examine my own views of what constitutes a good entrepreneur capable } \\
\text { of creating jobs }\end{array}$ & CR4 & 0.94 & 0.94 & 0.95 & 0.86 & 0.93 & 0.05 \\
\hline \multicolumn{8}{|l|}{ Renewed pedagogical approaches and competencies (REPAC) } \\
\hline $\begin{array}{l}\text { I will be better prepared as a result of renewed pedagogical approaches and competencies } \\
\text { of my teachers }\end{array}$ & REPAC4 & 0.76 & & & & & \\
\hline $\begin{array}{l}\text { I will benefit from knowledge exchange, aimed at promoting product/process innovation } \\
\text { or new pedagogy }\end{array}$ & REPAC5 & 0.79 & & & & & \\
\hline $\begin{array}{l}\text { My entrepreneurial knowledge and skills will improve through improved teaching } \\
\text { approaches }\end{array}$ & REPAC8 & 0.83 & 0.81 & 0.81 & 0.56 & 0.77 & 0.09 \\
\hline \multicolumn{8}{|l|}{ Building linkages between higher education and industry (BELHI) } \\
\hline $\begin{array}{l}\text { My entrepreneurial intentions will improve as a result of effective linkages between my } \\
\text { university and industry }\end{array}$ & BELHI3 & 0.70 & & & & & \\
\hline $\begin{array}{l}\text { I will apply the knowledge acquired throughout job creation seminars, workshops and } \\
\text { conferences organized by industry in collaboration with my institutions }\end{array}$ & BELHI7 & 0.67 & & & & & \\
\hline $\begin{array}{l}\text { I can be linked to industry experts for business development mentoring, and become } \\
\text { familiarized with new technologies for business start-up and development }\end{array}$ & BELHI8 & 0.76 & 0.76 & 0.77 & 0.58 & 0.76 & 0.13 \\
\hline \multicolumn{8}{|l|}{ Career training and mentoring (CTM) } \\
\hline I will learn more strategies for achieving my career aspirations & CTM1 & 0.77 & & & & & \\
\hline I will gain more advice and guidance on how to attain business recognition & CTM5 & 0.90 & & & & & \\
\hline I will gain the right information about various aspects of my career in business venturing & CTM8 & 0.89 & 0.89 & 0.88 & 0.73 & 0.85 & 0.19 \\
\hline
\end{tabular}




\begin{tabular}{|c|c|c|c|c|c|c|c|}
\hline A career as an entrepreneur is attractive to me & ATB4 & 0.76 & & & & & \\
\hline Being a business owner who can create jobs would give me great satisfaction & ATB7 & 0.74 & 0.87 & 0.89 & 0.81 & 0.89 & 0.18 \\
\hline \multicolumn{8}{|l|}{ Self-efficacy } \\
\hline I possess the ability to be an entrepreneur & Selfe5 & 0.92 & & & & & \\
\hline I have the ability to make decisions after deliberation & Selfe6 & 0.91 & & & & & \\
\hline I can find business partners who complement my ability & Selfe 8 & 0.98 & 0.95 & 0.96 & 0.89 & 0.94 & 0.05 \\
\hline \multicolumn{8}{|l|}{ Student job creation intention } \\
\hline I am determined to create my own business after graduation to create jobs & JCI2 & 0.84 & & & & & \\
\hline I have got the intention to start my own business after graduation & JCI3 & 0.73 & & & & & \\
\hline My professional goal is to own a business after graduation so that I can create jobs & JCI4 & 0.82 & 0.85 & 0.85 & 0.66 & 0.81 & 0.13 \\
\hline
\end{tabular}


Table 2. Mean, standard deviation, and bivariate correlations among variables.

\begin{tabular}{llcccccccccc}
\hline & Mean & SD & $\mathbf{1}$ & $\mathbf{2}$ & $\mathbf{3}$ & $\mathbf{4}$ & $\mathbf{5}$ & $\mathbf{6}$ & $\mathbf{7}$ & $\mathbf{8}$ \\
\hline 1 & Gender & 1.48 & 0.5 & 1 & & & & & & & \\
2 & Age & 1.46 & 0.5 & $0.36^{* *}$ & 1 & & & & & & \\
3 & Curriculum Restructuring & 10.48 & 4.24 & 0.07 & $0.16^{* *}$ & 1 & & & & & \\
4 & REPAC & 8.54 & 4.571 & 0.07 & -0.12 & -0.02 & 1 & & & & \\
5 & BELHI & 13.36 & 2.573 & 0.04 & -0.05 & -0.02 & 0.04 & 1 & & & \\
6 & CTM & 12.88 & 3.295 & 0.11 & 0.12 & 0.04 & 0.08 & 0.02 & 1 & & \\
7 & ATB & 11.07 & 4.363 & -0.01 & -0.07 & -0.02 & $0.35^{* *}$ & 0.01 & $0.13^{*}$ & 1 & \\
8 & Self-Efficacy & 7.88 & 2.654 & $0.23^{* *}$ & 0.07 & $0.13^{*}$ & $0.16^{* *}$ & -0.07 & 0.08 & $0.16^{*}$ & 1 \\
9 & Student Job creation Intention & 11.11 & 4.11 & $0.13^{*}$ & $-0.17^{* *}$ & $0.17^{* *}$ & $0.40^{* *}$ & $0.17^{* *}$ & $0.18^{* *}$ & $0.26^{* *}$ & $0.43^{* *}$ \\
\hline
\end{tabular}

Source: Authors' computation. $\mathrm{N}=268 ; * p<0.05 ; * * p<0.01$ (2-tailed). 
Table 3. Results showing all direct effects and indirect effects.

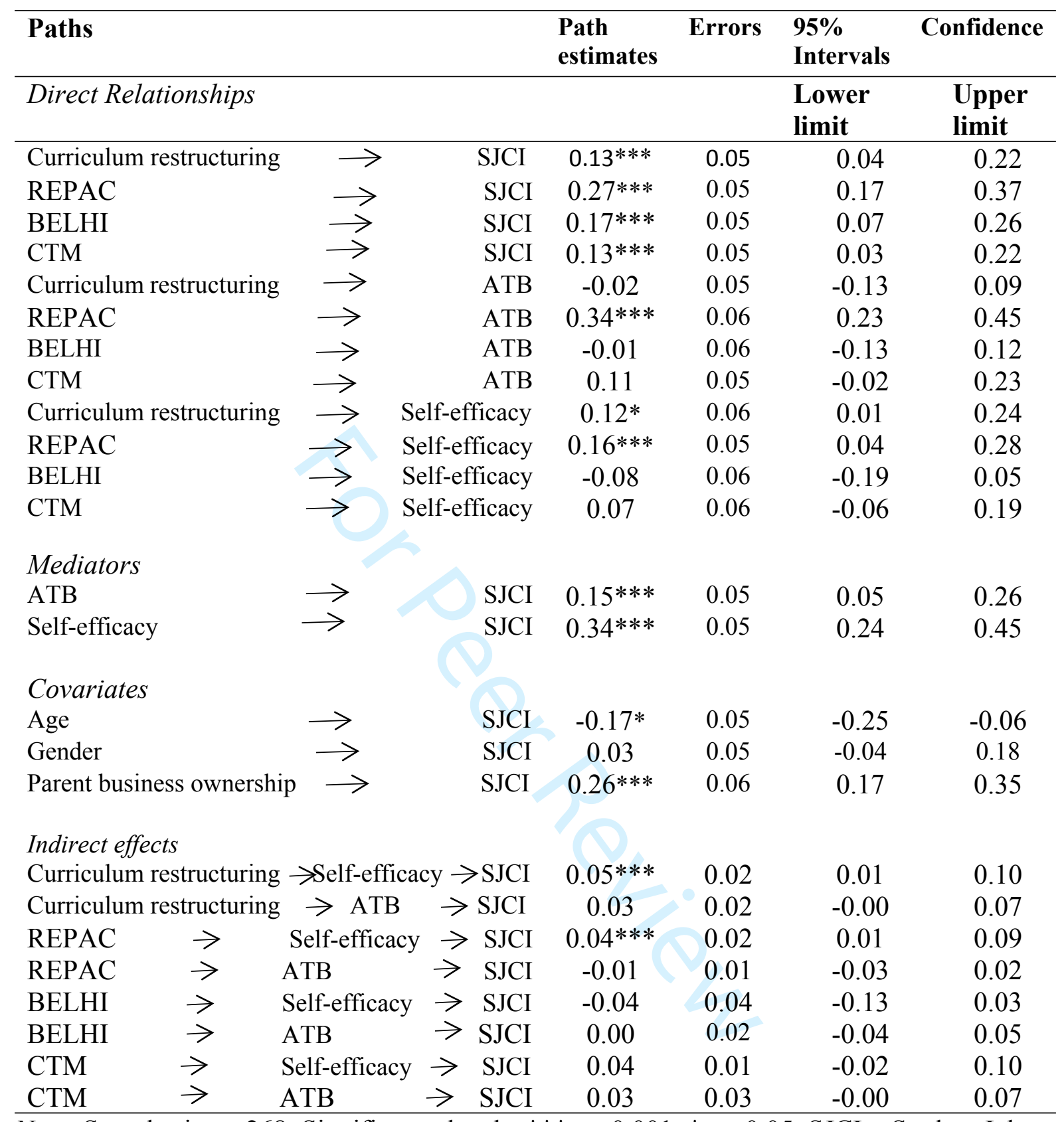

Note: Sample size $=268$; Significance levels: $* * * p<0.001 ; * p<0.05 ;$ SJCI $=$ Student Job Creation Intention; ATB $=$ Attitude Towards Behaviour. All individual standardized regression weights are reported.

Source: Authors' computation. 